\title{
Angiogenic activity of Calendula officinalis flowers L. in rats ${ }^{1}$
}

\author{
Atividade angiogênica das flores da Calendula officinalis L. em ratos
}

\author{
Leila Maria Leal ParenteI, Maria Auxiliadora AndradeII, Luiz Augusto Batista Brito ${ }^{\text {III, }}$ Veridiana Maria Brianezi Dignani \\ de Mouraıv, Marina Pacheco Miguelv, Ruy de Souza Lino-Júnior ${ }^{\mathrm{VI}}$, Leonice Faustino Manrique Tresvenzol ${ }^{\mathrm{VII}}$, José Realino de \\ Paula ${ }^{\text {III }}$, Neusa Margarida Paulo \\ ${ }^{1}$ Research performed at Departments of Pathology, Preventive Medicine and Natural Products Laboratory, Federal University of Goias (UFG), \\ Brazil.

\begin{abstract}
${ }^{\mathrm{I}} \mathrm{PhD}$ in Animal Science, Department of Pathology, Veterinary School, UFG, Goias, Brazil. Conception and design, data acquisition, statistical analysis and interpretation, manuscript writing.

II Associate Professor, Preventive Medicine Department, Veterinary School, UFG, Goias, Brazil. Involved in technical procedures.

${ }^{\text {III }} \mathrm{PhD}$, Full Professor, Animal Pathology Department, Veterinary Medicine School, UFG. Goias-GO, Brazil. Manuscript writing and critical revision.

${ }^{\mathrm{IV}}$ Associate Professor, Pathology Department, Veterinary Medicine School, UFG, Goias, Brazil. Manuscript writing and critical revision.

${ }^{v} \mathrm{PhD}$, Assistant Professor, Biomedicine Department, UFG, Campus Jatai, Goias, Brazil. Involved in technical procedures.

${ }^{\mathrm{V}} \mathrm{PhD}$, Associate Professor, General Pathology Department, Institute of Tropical Pathology and Public Health, UFG, Goias, Brazil. Morphometric analysis, statistical analysis, technical procedures.

VII Associate Professor, Natural Products Laboratory, Pharmacy School, UFG, Goias, Brazil. Data acquisition, collection and processing of study intormations.

${ }^{V I I I}$ Assistant Professor, Veterinary Medicine Department of, Veterinary School, UFG, Goias, Brazil. Conception and design, intellectual and scientific content of the study, critical revision.
\end{abstract}

\begin{abstract}
Purpose: In this work, angiogenic activity of Calendula officinalis L. (Asteraceae) ethanolic extract and dichloromethane and hexanic fractions were evaluated, considering medicinal properties, especially healing activity, are attributed to this plant. Methods: Models using 36 rats and 90 embryonated eggs were used to evaluate healing and angiogenic activities of extracts and fractions of the plant, through the induction of skin wounds and the chorioallantoic membrane, respectively. The effect of vascular proliferation was also tested from the study to verify the intensity of expression of vascular endothelial growth factor (VEGF) in cutaneous wounds in rats. Results: The angiogenic activity of the extract and the fractions was evidenced in both experimental models. It was verified that this effect is not directly related to the expression of VEGF and it could be associated to other pro-angiogenic factors. Conclusion: The healing activity referred to C. officinalis is related, among other factors, to its positive effect on angiogenesis, characterized by the induction of neovascularization.

Key words: Calendula. Wound Healing. Neovascularization, Physiologic. Plants, Medicinal. Rats.
\end{abstract}

\section{RESUMO}

Objetivo: Neste trabalho a atividade sobre a angiogênese do extrato etanólico (EEC) e das frações diclorometano e hexânica das flores de Calendula officinalis L. (Asteraceae) cultivada no Brasil foram avaliados, visto que propriedades medicinais têm sido atribuídas às flores da planta, destacando-se a atividade cicatrizante. Métodos: Modelos utilizando 36 ratos e 90 ovos embrionados foram usados para avaliar as atividades cicatrizante e angiogênica dos extratos e frações da planta, por meio da indução de feridas cutâneas e da membrana corioalantóide, respectivamente. O efeito proliferativo vascular foi também testado a partir do estudo imunoistoquímico, realizado para verificar a intensidade da expressão do fator de crescimento endotelial vascular (VEGF) na derme de ratos. Resultados: A atividade angiogênica do extrato e das frações foi evidenciada nos dois modelos experimentais empregados. Foi evidenciado que este efeito não estava diretamente relacionado à expressão do VEGF, podendo estar associado a outros fatores pró-angiogênicos. Conclusão: A atividade cicatrizante referida a C. officinalis está relacionada ao seu efeito positivo sobre a angiogênese, e este foi caracterizado pela indução de neovascularização.

Descritores: Calendula. Cicatrização de Feridas. Neovascularização Fisiológica. Plantas Medicinais. Ratos. 


\section{Introduction}

Since the Antiquity, medicinal properties have been attributed to the flower commonly known as calendula (Calendula officinalis L.), from the Asteraceae family. It seems that its use has been more disseminated from the XIII century on, and it was initially utilized for healing wounds. It was employed as unguent and ointment, as an antiseptic and an anti-inflammatory, during the North American Civil War and the World War ${ }^{1-5}$.

Few experimental models have been carried out for the evaluation of the anti-inflammatory activity of the $C$. officinalis. One of these models was conducted by means of the induction of ear edema by croton oil and another one by the use of carrageenan-induced paw edema ${ }^{4-6}$.

Patrick et $a l{ }^{7}$ carried out a study with European $C$. officinalis flowers by the use of the chorioallantoic membrane (CAM) of chicken fertilized egg. They demonstrated the inductive role of the plant on the microvascularization. The CAM has been often used in the assessment os substances with pro-angiogenic activity, such as the vascular endothelial growth factor (VEGF), and antiangiogenic, such as the endostatin ${ }^{8-10}$.

The CAM is transparent, composed by a highly vascular mesoderm, which is part of the three extra-embryonic membranes that protect and nourish the embryo ${ }^{11}$. The use of CAM as an experimental model is justified because it is simpler and cheaper than the use of mammals. The FDA (United States Food and Drug Administration) has aproved the carrying out of pre-clinical evaluations with this experimental model in studies of substances employed in the treatment of chronic cutaneous ulcers and burn wounds $^{8-12}$. The quantitation of angiogenic response in the CAM can be carried out by manual score, morphometry with the aid of softwares, or the imaged points count ${ }^{13}$.

In this study, we aimed to evaluate the angiogenic activity of the ethanolic extract and its fractions produced from C. officinalis flowers (CEE) cultivated in Brazil. For that, models of CAM of fertilized chicken eggs and of mice's cutaneous wounds were used. The immunohistochemical technique was used to evaluate the effect of the CEE in the angiogenesis and in the expression of vascular endothelial growth factor (VEGF) on rats's derm.

\section{Methods}

\section{Preparation of the ethanolic extract and its fracions}

Dry and pulverized C. officinalis flowers from Parana State (February, 2006) were obtained at the company Empresa Clorofila (Goiania-GO, Brazil). As for quality control, pharmacognostic evaluation of this vegetal species was carried out at the Laboratory of Natual Products Research, from the Phamarcy Faculty, Federal University of Goias, according to the techniques described by the Brazilian Pharmacopeia $\mathrm{IV}^{14}$.
To obtain the ethanolic extract (CEE), 200g of the pulverized flowers were extract with $100 \mathrm{~mL}$ of ethanol PA $96^{\circ}$ GL, by maceration, for three days, at room temperature, with occasionally shaking, and concentrated in a rotary evaporator at $40^{\circ} \mathrm{C}$.

Hexanic and dichloromethane fractions were obtained from $10 \mathrm{~g}$ of the $\mathrm{CEE}$, which was solubilized in a methanol/ $\mathrm{H}_{2} \mathrm{O}$ $(7: 1)$ mixture and firstly extracted three times with $50 \mathrm{~mL}$ of hexane and, later, extracted three times with $50 \mathrm{~mL}$ of dichloromethane. The extracts were concentrated on a rotary evaporator. Ethanolic extract and hexanic and dichloromethane fractions solutions at $1 \%$, solubilized in $70 \%$ ethanol, were prepared to evaluate the angiogenic activity in the CAM. To evaluate the angiogenic activity in cutaneous wounds on rat's derm, a CEE aqueous solution at $1 \%$ was daily prepared.

\section{Experimental animals}

The experimental protocol with the animals used in this study was approved by the Research Ethics Comitee of the Federal University of Goias, under the number 019/2007. Twelve female rats (Rattus norvegicus albinus), Wistar lineage, at 80 days of age, weight of 150-200g were used. Animals came from the Animal Colony of the Federal University of Goias (UFG), Goiania-GO, Brazil. Animals were adapted at the Experimental Surgery of the Veterinary School, UFG, for 10 days, and kept in individual polyethylene cages covered with coarse sawdust, under controled environmental conditions (temperature at $23 \pm 2{ }^{\circ} \mathrm{C}$, relative humidity of air at $50-70 \%$, and 12 -hour-light/ dark photoperiod). Water and ration were supplied ad libitum.

\section{Chorioallantoic membrane (CAM) model}

\section{Preparing the CAM}

The CAM was prepared for the evaluation of the angiogenic activity according to methodology adapted from Kim et al. ${ }^{16}$ Ninety 2-year-old embryonated eggs of Cobb chicken, obtained from 34-35 week-old female broiler breeders, were used. The eggs were placed in incubators (Premium Ecológica IP-130), under invariable humidity $(67.5 \%)$ and temperature at $37^{\circ} \mathrm{C}$, and randomly divided into six groups with 15 eggs each to undergo the following treatments: $\mathrm{SC}_{1}=$ solvent control (ethanol $70 \%$ ); $\mathrm{SC}_{2}=$ distilled water; $\mathrm{PC}=$ positive control at $1 \%$ (17 ß-estradiol); $\mathrm{CEE}=$ ethanolic extract $1 \%$; DCF $=$ dichloromethane fraction $1 \%$; and $\mathrm{HCF}=$ hexanic fraction $1 \%$.

Egg shell opening, albumen withdrawn and the treatments were performed in a Chamber of Biological Safe type II. On the third incubation day, 2-3 mL of albumen were withdrawn, through a small opening in the shell. Later, the opening was sealed with histological paraffin at melting point. Incubation continued until the tenth day, when the eggs were treated with $0.1 \mathrm{~mL}$ of the solution specific to each group, instilled on the CAM surface. 
The eggs were resealed and incubated for two more days. After the embryos euthanasia by medullar section at the atlanto-occipital joint, the CAM fragments of each egg were collected for morphometric analysis and quantitation of the number of blood vessels.

\section{CAM morphometric evaluation}

As for the morphometric analysis, a fragment of fresh CAM of ten eggs from each group was collected and expanded on a glass slide, over which a coverslip was superposed.

The slides reading was carried oud with the aid of an image digital analysis system, that is, a digital videocamera (Sony Cyber-Shot 3.2 MP, model DSC-P71) that transmits the captured imaged from the microscope (Carl Zeiss ${ }^{\odot}$, model Jenaval, with plan achromatic objectives) to a computer (Pentium ${ }^{\circledR} 4,3,20 \mathrm{GHz}$, 1 GB RAM memory), with digitizing board and software Image J 1.3.1, NIH, United States. The percentage of vascular area per field, matching the red marked areas, was calculated in a Windows environmet. Thirty random fields that presented blood vessels were photographed.

\section{blood vessels}

Evaluation of the inflammatory cells and of the CAM

The membranes fixed in buffered formaline were processed, included in paraffin, and stained by the hematoxylin and eosin technique. The images were captured as described above. The inflammatory cells present in the CAM were evaluated in twenty randomly photographed fields. The results were visually classified according to the intensity found, and the data were transformed into quantitative variables, by assigning the following scores: absent (0), discrete ( 1 to $25 \%$ ), moderate (25 to $50 \%$ ), and accentuated (over $50 \%$ ).

Blood vessels count of the CAM mesoderm was carried out by the use of planimetry by point counting, with the aid of the software GIMP 2.4.3. A square lattice composed by 25 points was suporposed to the histological image, and only the vessels in the interssections within the visual field were counted, according to the models suggested by Ribatti et al. ${ }^{11}$ and Prado et al. ${ }^{16}$.

\section{Rat's cutaneous wound model}

The animals were randomly distributed into two groups with six animals each and submitted to the treatments: SC solvent control (distilled water) and CEE - ethanolic extract $1 \%$.

To induce the wounds, a circular metal punch $(1 \mathrm{~cm}$ diam) was used in the dorsocervical region of each animal. The anesthesia consisted of the administration of ketamine (70 $\mathrm{mg} / \mathrm{Kg}, \mathrm{IM})$ and xylazine $(10 \mathrm{mg} / \mathrm{Kg}$, IM). After the surgery, $100 \mu \mathrm{L}$ of the test solution (CEE) and solvent wore instilled on the wounds. This procedure was repeated daily at the same time. On the 7 th day of the postoperative period, the animals were submitted to euthanasia in $\mathrm{CO}_{2}$ chamber, in order to collect a skin fragment from the surgical wound area. The fragments were preserved in $10 \%$ buffered formol.

Tissue sections $(5 \mu \mathrm{m})$ were expanded on silane-coated histological slides (3, aminopropyl-triethoxysilane, Sigma Aldrich, USA), and kept in a hothouse at $36^{\circ} \mathrm{C}$ for a better tissue adhesion to the slide. After that, the sections were deparaffinized and rehydrated. Then, the antigenic recovery was performed in a citrate solution $(\mathrm{pH} 6.0)$, in a water bath at $95^{\circ} \mathrm{C}$, for 30 minutes, followed by endogenous peroxidase blocking. The slides were incubated in bovine serum albumin (BSA) at 3\%, for one hour, at room temperature in a wet chamber, in order to block unespecific marking.

After that, the slides were incubated in VEGF primary antibody (147) (Santa Cruz Biotechnology, Antibody sc-507), 1:500 dilution, in wet chamber, overnight, at $4^{\circ} \mathrm{C}$. Then the streptavidin-biotin-peroxidase complex (kit LSAB - Dako K0690) was instilled on the slides for 20 minutes each reaction, in a wet chamber at room temperature. The reaction was revealed with diaminobenzidine (DAB) solution, for 1 minute. A PBS solution was used for washing between the steps. The sections were counterstained with Mayer's hematoxylin, for 30 seconds, and the slides were mounted with synthetic resin (Sigma Aldrich, USA) and histological coverslips. As for negative control, the skin samples were incubated with TRIS buffer, $\mathrm{pH}$ 7.4.

Derm images were captured by the same procedures used to capture CAM images. Planimetry by point counting was used to count blood vessels and to evaluate the intensity of VEGF expression in endothelial cells.

The histological slides preparation, the photomicrographies of the fresh CAM fragments, morphometric analysis, and planimetry by point counting were performed by the same observer.

\section{Statistical analysis}

The results were submitted to statistical treatment by the use of GraphPad InStat software (Version 3.05 for Windows). From the Kolmogorov-Smirnov test for normality, the CAM data were evaluated by Kruskal-Wallis test and then by Dunn post-test. The data analysis of immunoistochemistry of the mice's skin fragments was performed by means of the Mann-Whitney test. The significance level was $\mathrm{p}<0.05^{17}$.

\section{Results}

\section{Chorioallantoic membrane}

In morphometric evaluation increase of the vascular area and of percentage of red-marked areas was observed in CAM treated as positive control $1 \%$ (17 B-estradiol), ethanolic extract $1 \%$, dichloromethane fraction $1 \%$ and hexanic fraction $1 \%$, compared to solvent control (ethanol 70\%). No differences were observed regarding the same parameter among the following groups: positive control $1 \%$, ethanolic extract $1 \%$, dichloromethane fraction $1 \%$ and hexanic fraction $1 \%$ (Figures 1 and 2 ). 

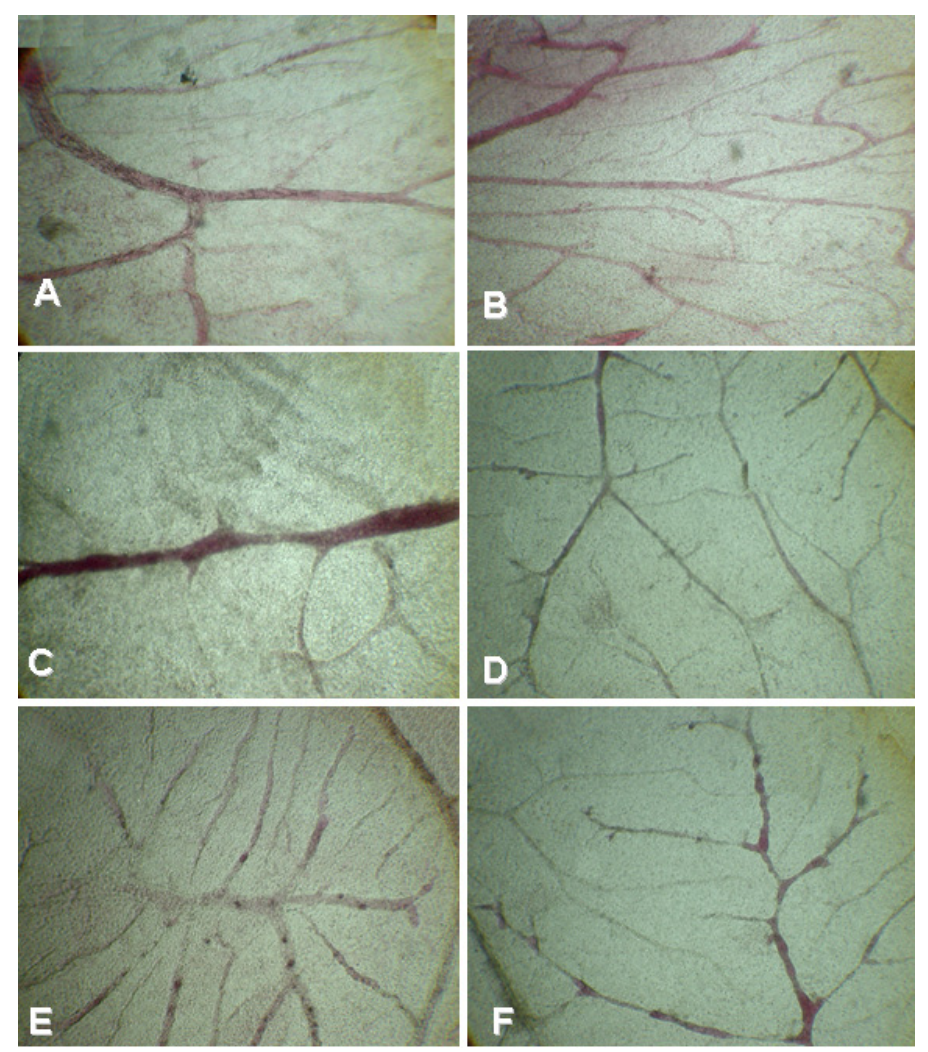

FIGURE 1 - A. Fresh chorioallantoic membrane of embryonated chicken eggs treated as distilled water. B. Positive control (17 ß-estradiol). C. Solvent control (etanol 70\%). D. Ethanolic extract. E. Hexanic fraction. F. Dichloromethane fraction. $5 x$.

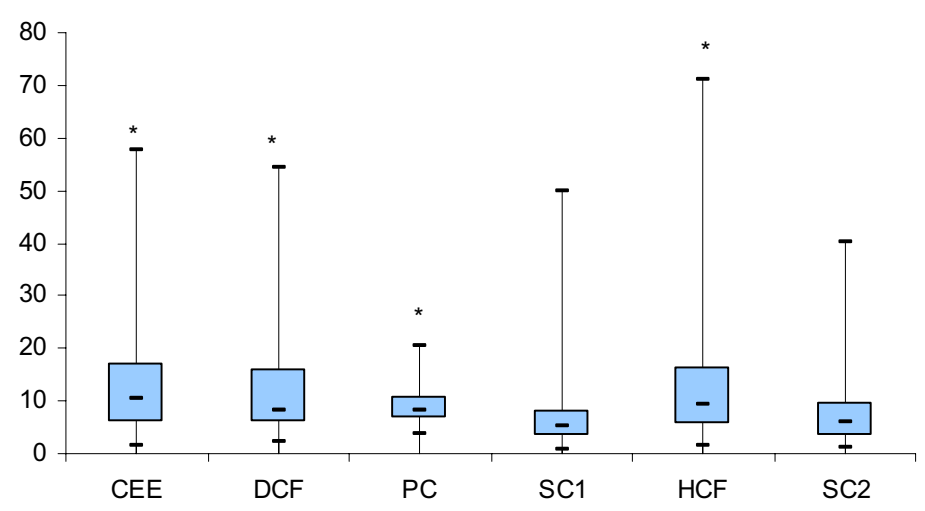

FIGURE 2 - Morphometry of fresh chorioallantoic membrane of embryonated chicken eggs. ${ }^{*} \mathrm{p}<0.05$ significant difference related to ethanol $70 \%$ control group (SC1).

The presence of inflammatory cells in CAM stained with hematoxylin and eosin was discrete in all evaluated groups, with predominance of heterofile polymorphonuclears, indicating that the effects of the observed treatments are not related to inflammatory activity.
The quantitation of blood vessels, carried out by planimetry in CAM stained with hematoxylin-eosin and treated with positive control 1\% (17 ß-estradiol), C.officinalis flowers ethanolic extract $1 \%$, dichloromethane fraction $1 \%$ and hexanic fraction $1 \%$, indicated vessels increase compared to solvent control (ethanol 70\%). No significant differences were observed regarding the same parameter among the following groups: positive control $1 \%$, ethanolic extract $1 \%$, dichloromethane fraction $1 \%$ and hexanic fraction $1 \%$ (Figure 3 ).

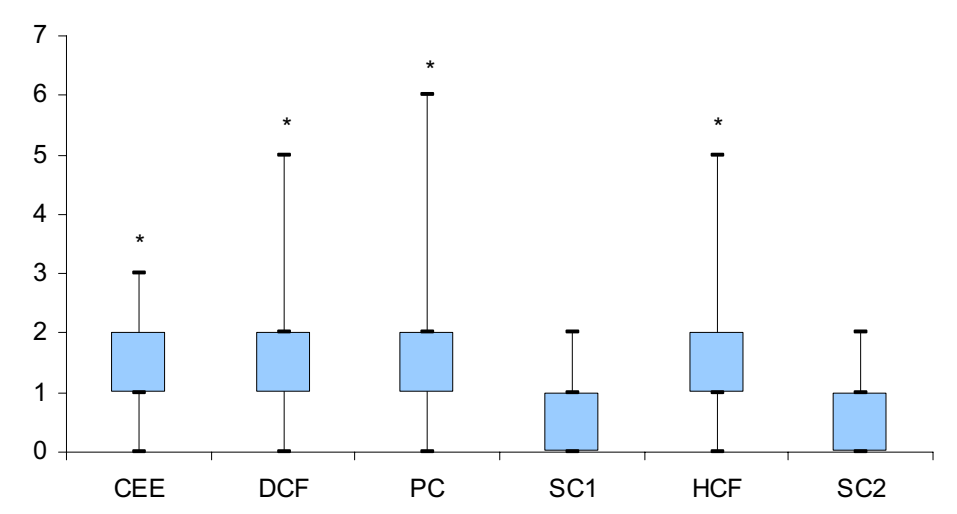

FIGURE 3 - Influence of treatments on the number of blood vessels of chorioallantoic membrane of embryonated chicken eggs. ${ }^{*} \mathrm{p}<0.05$ significant difference related to ethanol $70 \%$ control group (SC1).

\section{Rat's cutaneous wounds}

Digital planimetry by point counting performed on mice derm trated with ethanolic extract $1 \%$ revealed an increase in the number of blood vessels compared to solvent control (Figures 4 and 5). There was significant difference among the groups. As for intensity of VEGF espression in endothelial cells, there was no significant difference among the groups.

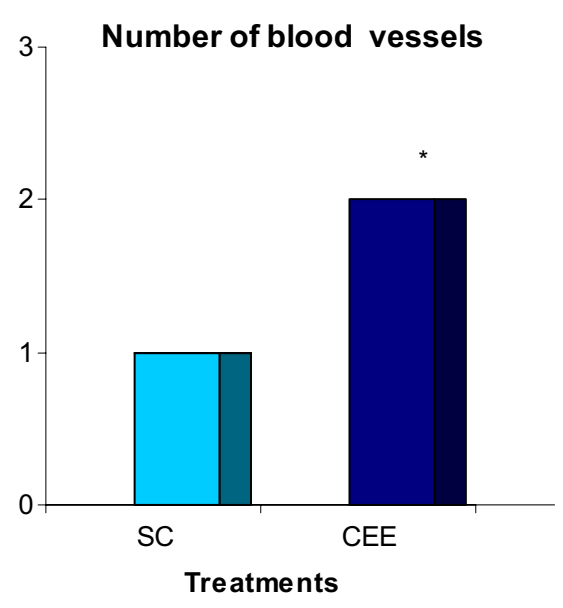

FIGURE 4 - Effect of solvent control (SC) and of Calendula officinalis flowers ethanolic extract $1 \%$ (CEE) on the number of blood vessel in rat's derm $\left({ }^{*} \mathrm{p}<0.05\right)$. 


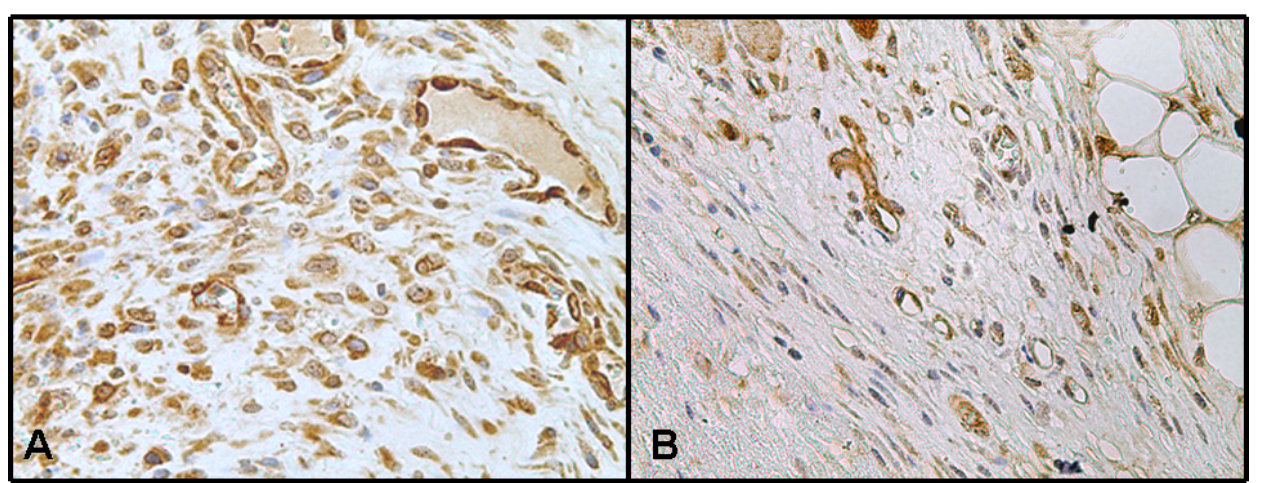

FIGURE 5 - (A) Solvent control (distilled water). (B) Calendula officinalis flowers ethanolic extract $1 \%$ in rat's derm. IHQ, 400x.

\section{Discussion}

The increase of chorioallantoic membrane vascular area of CEE, DCF and HCF indicated a positive effect of these compounds on angiogenesis. This activity was confirmed by the quantitation of menbrane blood vessel on the histological sections. The results demonstrated that ethanolic extract and dichloromethane and hexanic fractions of Calendula officinalis flowers present inducer effect on the angiogenesis process. The same results were described by Patrick et $a l .{ }^{7}$ when they used an aqueous extract of $C$. officinalis grown in England.

From the CEE fractioning, the obtaiment of dichloromethane, hexanic, ethyl acetate and methanol-water fraction was possible. However, in this experiment, only the angiogenic effects of ethanolic extract and of the dichloromethane and hexanic fraction were tested, because Patrick et al. ${ }^{7}$ had already proved the angiogenic activity of calendula aqueous extract. Therefore, the angiogenic activity was verified in less polar fractions (dichloromethane and hexanic), considering Moom et al. ${ }^{18}$, $\mathrm{Hsu}^{19}$ and Leung et al. ${ }^{20}$ pointed out that compounds with such polarity have saponins and flavonoids, which may present angiogenic activity.

Many compounds are present in the crude extract of a plant. Together or not, these extracts are responsible for certain biological activity ${ }^{21}$. In this study, CEE, DCF and HCF angiogenic effect of $C$. officinalis on CAM was verified, suggesting that both extract and fractions present compounds responsible for the observed vascular proliferative effects. In the way, Volpato ${ }^{22}$ determined, by chromatographic estudies, that dichloromethane and hexanic fractions of Brazilian C. officinalis flowers are rich in triterpenes and steroids. Besides, Della-Loggia et al. $^{5}$ related calendula antiinflammatory activity to the presence of treterpenes. Thus the angiogenic activity verified in this work can be related mainly to these two compound classes, triterpenes and steroids, that are probably present in both extract and fractions of calendula flowers.

When substances are administered on CAM surface, unespecific inflammatory reaction may occur, inducing to a secondary vascular proliferative response ${ }^{11}$. In this work, CAM treated with calendula extract or fraction presented discrete inflammatory infiltrate. Also, ethanol and distilled water were used as solvent control in the experiment in order to verify if the ethanol would present any irritation on CAM. Therefore, it can be concluded that the increase of neovascularization observed in CAM is due to the C. officinalis direct activity on the membrane, and it is not related to the inflammatory reaction, confirming the findings by Patrick et al. ${ }^{7}$.

The increase of the number of blood vessels on rat's derm treated with ethanolic extract and verified by positive immunohistochemical for VEGF confirmed the intense activity on the neovacularization promoted by CEE in CAM model. The immunohistochemical technique, as a viable way for angiogenesis evaluation by positive marking for VEGF in this experimental model, indicated that the CEE angiogenic activity is not directly related to the increase of expression of this groth factor. Carmeliet ${ }^{23-24}$ observed that other proangiogenic factors, such as fibroblasts growth factors (FGF), or angiogenic cytokines, such as interleukin-8 (ILL-8), tumor necrosis factor- $\alpha$ (TNF- $\alpha$ ) and transformation and growth factor- $\beta$ (TGF- $\beta$ ), may also be related to angiogenesis mechanisms. This way, it is possible that other factors are involved in vascular proliferation generated by calendula flowers extract, verified in this work.

\section{Conclusion}

Calendula officinalis grown in Brazil showed accentuated angiogenic activity in both models used: chorioallantoic membrane of chicken fertilized eggs and rat's cutaneous wounds.

\section{References}

1. Re T A, Mooney D, Antignac E, Dufour, E, Bark I, Srinivasan V, Nohynek G. Application of the threshold of toxicological concern approach for thesafety evaluation of calendula flower (Calendula officinalis) petals and extracts used in cosmetic and personal care products. Food Chem Toxicol. 2009;47:1246-54. 
2. Pommier P, Gomez F, Sunyach MP, D'Hombres A, Carrie C, Montbarbon X. Phase III randomized trial of Calendula officinalis compared with trolamine for the prevention of acute dermatitis during irradiation for breast cancer. J Clin Oncol. 2004;22:1447-53.

3. Zitterl-Eglseer K, Sosa S, Jurenitsch J, Schubert-Zssilavecz M, Della Loggia R,Tubaro A, Bertoldi M, Franz C. Anti-oedematous activities of the main triterpendiol esters of marigold (Calendula officinalis L.). J Ethnopharmacol. 1997;57:139-44.

4. Brown DJ, Dattner AM. Phytotherapeutic approaches to common dermatologic conditions. Arch Dermatol. 1998;134:1401-4.

5. Della-Loggia R, Tubaro A, Sosa S, Becker H, Isaac O. The role of triterpenoids in the topical anti-inflammatory activity of Calendula officinalis flowers. Planta Med. 1994;60:516-20.

6. Hamburguer M, Adler S, Baumann D, Forg A, Weinreich B. Preparative purification of the major anti-inflammatory triterpenoid ester from Marigold (Calendula officinalis). Fitoterapia. 2003;74:328-38.

7. Hazel SJ. A novel early chorioallantoic membrane assay demonstrates quantitative and qualitative changes caused by antiangiogenic substances. J Lab Clin Med. 2003;141:217-28.

8. RibattiI D, Vacca A, Roncali L, Dammacco F. The chick embryo membrane as model for in vivo research on anti-angiogenesis. Curr Pharmacol Biotechnol. 2000;1:73-82.

9. Farmacopéia Brasileira IV. Atheneu: São Paulo; 2001.
10. Kim MS, Lee YM, Moon EJ, Kim SE, Lee JJ, Kim KW. Anti-angiogenic activity of torilin, a sesquiterpene compound from Torilis japonica. Int J Cancer 2000;87:269-75.

11. Prado FA, Anbinder AL, Jaime, APG, Lima AP, Balducci I, Rocha RF. Defeitos ósseos em tibias de ratos: padronização do modelo experimental. Rev Odontol UNICID. 2006;18(1):7-13.

12. Sampaio IBM. Estatística aplicada à experimentação animal Belo Horizonte: Fundação de Ensino e Pesquisa em Medicina Veterinária; 1998. 13. Moom EJ, Lee YM, Lee OH, Lee MJ, Lee SK, Chung MH. A novel angiogenic factor derived from Aloe vera gel: b-sitosterol, a plant sterol. Angiogenesis. 1999;3:117-23.

14. Hsu S. Green tea and the skin. J Am Acad Dermatol. 2005;52:1049-59. 15. Carmeliet P. Mechanisms of angiogenesis and arteriogenesis: Review. Nature Am. 2000;6(3):389-95.

16. Carmeliet P. Angiogenesis in health and disease: Review. Nature Med. 2003;9(6):653-60.

\section{Acknowledgements}

To the Company Perdigao S/A (Rio Verde-GO) for rendering available the embryonated eggs. To the Animal Colony of Federal University of Goias for giving the Wistar rats (Rattus norvegicus albinus).

\section{Correspondence:}

Leila Maria Leal Parente

Campus II Samambaia,

Caixa Postal 131

74001- 970 Goiânia-GO Brasil

Phone/Fax: (55 62)8431-1906 / 3521-1566

lathosvet@,hotmail.com

Conflict of interest: none

Financial source: CAPES

Received: July 12, 2010

Review: September 20, 2010

Accepted: October 21, 2010 
This article has received corrections asked by theeditor on A pr/2011 in agreement with the ERRATUM published in Volume 26 Number 2. (http://www.scielo.br/pdf/acb/v26n2/v26n2a15.pdf) 